\title{
El Museo del Prado en la narrativa española contemporánea en la transición del siglo XX al XXI. Entre la realidad y la ficción
}

\author{
María VilLALBA SALVADOR \\ Universidad Autónoma ed Madrid
}

\begin{abstract}
RESUMEN. Este artículo trata sobre la narrativa contemporánea española en relación con la gran pinacoteca española: el Museo del Prado. Son muchas las obras que se inspiran en el Museo del Prado como recinto, lugar de trabajo y custodio de nuestro Patrimonio Cultural, y muchas las obras colgadas en sus paredes o guardadas en almacenes que han inspirado la creación de personajes protagonistas o secundarios de novelas históricas, novelas cortas, cuentos y relatos. En ellas se produce una combinación ingeniosa entre la realidad y la ficción, al tiempo que suponen un modo de difusión de nuestra riqueza patrimonial y un acicate para la visita a la colección del Museo del Prado. Son ejemplos de creaciones literarias que evidencian que las grandes obras siempre permiten nuevas relecturas e interpretaciones.

Palabras clave: Museo del Prado, Patrimonio Cultural, Arte y Literatura, Novela histórica, Ficción y realidad, Narrativa contemporánea española, Difusión, Guerra civil española (1936-1939).
\end{abstract}

ABSTRACT. The following article discusses the Spanish contemporary literature in connection with the great Spanish gallery: Museo Nacional del Prado. Many paintings are inspired in the Prado Museum as an institution, work centre and guard of our Cultural Heritage. Likewise, a lot of paintings shown on its walls and kept in its stores have inspired the creation of main and secondary characters of historic novels, short stories and tales. These works are an ingenious combination of reality and fiction and help to the purpose of communicating our heritage wealth and an incentive to visit the Museo del Prado collection. These are examples of literature works which evidence that the great paintings allow always new interpretations.

Key words: Museo del Prado, Cultural Heritage, Art and Literature, Historic novel, Fiction and reality, Contemporary Spanish narrative, Communication, Spanish Civil War (1936-1939).

"Al Museo del Prado, al cual adeudo muchas horas de felicidad" Manuel Mújica Laínez, 1984

Con esta dedicatoria comenzaba Manuel Mújica Laínez su obra Un novelista en el Museo del Prado, algo que yo podría suscribir en este momento, no sólo por las horas pasadas en el interior del Museo estudiando y contemplando sus obras maestras, sino por la cantidad de posibilidades de enriquecimiento personal a través de la lectura de obras narrativas, que surgen de ese mundo que es el Museo Nacional del Prado, y que, como las obras clásicas, es 
objeto constante de nuevas y sugerentes lecturas ${ }^{1}$.

A la vista de las numerosas obras que en los años más recientes encontramos en el mercado editorial sobre temas artísticos, y me refiero fundamentalmente a la última década del siglo XX y estos primeros años del siglo $X X I^{2}$, descubrimos una serie de obras en las que el Museo del Prado, de un modo $\mathrm{u}$ otro, se convierte en fuente de inspiración o en referencia necesaria. Bien como institución, bien como custodio de obras sugerentes para la creación de relatos de diversa índole $\mathrm{y}$, también, como reflexión y recuerdo en la mente de diferentes artistas contemporáneos. El tema del $\mathrm{Mu}$ seo del Prado como espacio literario ha sido estudiado por Javier Portús ${ }^{3}$, cuyo recorrido por la creación literaria del siglo XX recuerda obras narrativas como La maja desnuda, de Blasco Ibáñez o La Quimera, de Emilia Pardo Bazán, ambas de comienzos de siglo, que fueron seguidas por otras como Madrid de corte a checa (1938) de Agustín de Foxá, Calle de Echegaray (1950), de Marcial Suárez, así como el drama histórico Las Meninas

\footnotetext{
${ }^{1}$ El contenido de este artículo parte de la presentación de la ponencia «El Museo del Prado -entre la realidad y la ficción- en la narrativa española contemporánea» en las "IV Jornadas de Narrativa: Realidad y ficción en la narrativa contemporánea española" celebradas en Madrid en el CEU, Instituto de Humanidades Ángel Ayala, 14 y 15 de mayo de 2007.

${ }^{2}$ Vid. M. VIllalbA SAlVADOR, «Un panorama acerca de la novela y los escritos de arte en la narrativa de finales del siglo XX y comienzos del siglo XXI», en Ficción y realidad en la novela contemporánea española. Actas de las Jornadas de Narrativa Contemporánea Española, M. D. DE Asis GaRrote y A. CAlvo Revilla (eds.), Madrid, Universidad San Pablo CEU, 2005, 128-149; J. MARCHAMALO, «Pintar entre líneas», en Blanco y Negro Cultural, Madrid, núm. 679, 5 de febrero de 2005.

${ }^{3}$ Vid. J. PORTús, Museo del Prado. Memoria escrita 1819-1994, Madrid, Museo del Prado, 1994, pp. 87114;"La actividad bibliográfica", en Enciclopedia del Museo del Prado (dir. F. CAlvo SERRALlER y M. ZUGAZA MIRANDA), t. I: temático, Madrid, Fundación Amigos del Museo del Prado, Alcobendas (Madrid), TF, 2006, pp. 161-173.
}

(1960) de Antonio Buero Vallejo, entre otras muchas. De tal manera que, como señala Portús, es indudable que el Prado "desde hace décadas ha sido tácitamente reconocido como el principal depositario de la memoria colectiva nacional, lo que le convierte en algo más que una bellísima galería de pinturas y esculturas" ${ }^{\prime 4}$.

Es indudable la importancia y el peso histórico de sus colecciones que han generado una amplísima historiografía de carácter artístico ${ }^{5}$, como también quedan pocas dudas sobre el eco mediático de cualquier celebración, exposición, intervención o actuación arquitectónicas. El Museo del Prado siempre está en el punto de mira de la sociedad. Así ha sido desde mediados del siglo XIX, cuando fue descubierto por los viajeros del siglo XIX y así se nos muestra a lo largo del siglo XX y los inicios del nuevo siglo. $Y$ es una realidad que la atracción de esta institución trasciende lo puramente artístico y encuentra proyección en la literatura y sus distintos géneros. Algo que, por otra parte, como veremos, puede llegar a convertirse en fuente de inspiración y recurso para incrementar la difusión de los fondos del Museo a la sociedad.

\footnotetext{
${ }^{4}$ J. PORTús, Museo del Prado. Memoria escrita 18491994, Museo del Prado, Madrid, 1994, p.16.

${ }^{5}$ Merece recordar determinadas investigaciones sobre la obra de Benito Pérez Galdós, para el que el Museo del Prado y las obras en él custodiadas fueron en numerosas ocasiones referencias relevantes en sus novelas. Por ejemplo, J. J. ALFIERI, «El arte pictórico en las novelas de Galdós», Anales Galdosianos, 3, Austin, Texas, University of Texas, 1968, pp. 79-86; P. A. BLY, Vision and the visual arts in Galdós: a study of the novels and newspaper articles, Liverpool, Francis Cairns, 1986; Y. AREnCibia SANTANA, «Benito Pérez Galdós o el arte de la Pintura», La pintura del siglo XIX en las colecciones canarias. Los cimientos de la Modernidad, Las Palmas de Gran Canaria, Cabildo Insular de Gran Canaria, 1998, pp. 135-160. Asimismo, Pérez Galdós introduce la visión del Museo del Prado en la protagonista de su novela La Desheredada, la primera vez que acudía a la pinacoteca (Ed. E. MiLLARES), Barcelona, Planeta, 1992, pp. 61-62.
} 
En efecto, observamos que el Museo del Prado, en mayor medida que otras instituciones del mismo carácter, se ha convertido en objeto de atracción de la sociedad mediática y del llamado público potencial. En definitiva, en sujeto de novela, recinto, contenedor de obras del patrimonio colectivo, entorno de una realidad histórica y, ciertamente, en una realidad presente en nuestra vida susceptible de transformarse en ficción. Este artículo presenta algunos ejemplos significativos de esa cercanía entre la realidad y la ficción que es característica en determinados géneros narrativos de gran éxito en nuestro tiempo.

Pues bien, en el año 2002 obtenía el Premio Fernando Lara de Novela Los colores de la guerra ${ }^{6}$, obra de Juan Carlos Arce, jurista y experto en Derecho Comunitario, en la que consigue convertir en personaje de novela a nuestra gran pinacoteca. La novela se basa en el hecho histórico de la evacuación a Ginebra de las obras del Museo del Prado por la Junta del Tesoro Artístico. La idea de la importancia del acontecimiento y de lo que se está llevando a cabo subyace como una constante a lo largo de toda la narración, convirtiéndose en el hilo conductor inequívoco del texto. Juan Carlos Arce consigue crear una trama ágil en la que se superponen los planes de una facción y otra, mezclados con una historia de amor y espionaje con tintes claros de verosimilitud y en un entorno histórico documentado ${ }^{7}$. En diversas ocasiones, diferentes personajes exponen con rotundidad sus ideas respecto

${ }^{6}$ J.C. ARCE, Los colores de la guerra, Barcelona, Editorial Planeta, 2003.

${ }^{7}$ Vid. A. Colorado Castellary, el Museo del Prado y la Guerra civil. Figueras - Ginebra, 1939, Madrid, Museo del Prado, 1991; Éxodo y exilio del arte: la odisea del Museo del Prado durante la Guerra Civil, Madrid, Cátedra, 2008; I. Algerich, y J. ARA (eds.), Arte protegido. Memoria de la Junta del Tesoro Artístico durante la Guerra Civil, Madrid, Ministerio de Educación Cultura y Deporte, Secretaría General Técnica, Subdirección General de Información y Publicaciones, 2003. a las colecciones del Prado, tal como lo hace Avenol, Secretario General de la Sociedad de Naciones, en conversación con Jaujard, Subdirector del Museo del Louvre e interlocutor válido en aquel momento:

"El gobierno de Franco -señaló Avenolno se opone a cualquier evacuación, sino a que la Sociedad de Naciones participe en el salvamento. Quiere que lo haga la Cruz Roja. Y que lleven a Burgos las obras de arte. ¿Qué podemos hacer, entonces? El Museo del Prado no es de la República, sino de todos los españoles" ${ }^{8}$.

Más significativa, en este sentido, es la conversación entre Álvarez del Vayo, Ministro de Estado, y Timoteo Pérez Rubio 9 , que había sido Subdirector del Museo de Arte Moderno durante el gobierno de la República y fue nombrado, al comienzo de la Guerra Civil, Jefe de la Junta Central del Tesoro Artístico. Por lo tanto, responsable de trasladar las colecciones del Museo desde Madrid a Valencia, y de allí a Figueras. En definitiva de su salvamento y protección. La conversación transcurría en medio de serias dificultades aludiendo de nuevo a la idea de que el museo pertenece a todos los españoles, es patrimonio de la humanidad entera y la tarea de su conservación, de un modo acuciante, era responsabilidad del gobierno:

"Ministro - decía Pérez Rubio- , la Sociedad de Naciones no interviene ahora como no lo hizo hace un mes, cuando reclamamos su apoyo. Estamos solos. Nos han dejado solos a ti, al gobierno, a la República y al Museo del Prado. A nadie importan ya nuestras ideas ni nuestros cuadros.

-¿Qué podemos hacer?- preguntaba Vayo al aire y a la noche sin esperar respuesta.

-

${ }^{8}$ J. ARCE, Los colores de la guerra, Op. Cit, p. 26.

${ }^{9}$ Sobre Timoteo Pérez Rubio véase R. CHACEL, Timoteo Pérez Rubio y los retratos del jardín, Madrid, Cátedra, 1980; Obra completa, vol .8, Autobiografías, C. PÉREZ CHACEl y A. PIEDRA (eds.), Valladolid, Centro de Estudios Literarios, Fundación Jorge Guillén, Diputación Provincial de Valladolid, 2004, pp. 331-345. 
-Pensar en las generaciones futuras, en los pintores, en el arte, en la cultura. Pensar, Ministro -decía Pérez Rubio- en que esos cuadros son más importantes que la República y que esta maldita guerra. Evacuarlos urgentemente a donde sea, donde puedan preservarse ${ }^{10}$.

Pero se trata de un texto que presenta también traiciones a la historia, lógicas en el contexto de una novela histórica. Son muchos los personajes de la obra que reflejan fielmente la realidad, pero hay omisiones deliberadas del autor. Por ejemplo, la no presencia de José María Sert, persona decisiva en la negociación, o la participación de José Lino Vaamonde Valencia (1900-1986), arquitecto conservador del Museo del Prado y Vocal de la Junta Central de Incautación, Protección y Salvamento del Tesoro Artístico y encargado de la seguridad y de la recepción y habilitación de depósitos de las obras maestras trasladadas a Valencia para su conservación en dicha ciudad ${ }^{11}$. Del mismo modo, el autor se sirve de opciones legítimas en un género que se sitúa entre la invención y la realidad. Así, nos encontramos ante el supuesto robo de uno de los paisajes de Velázquez del Jardín de Villa Medicis, en medio de la evacuación desde

${ }^{10}$ Ibidem, pp. 47-48

11 Sobre este tema véase la comunicación de J. ARA, I. ALGERICH y R. BRUQUETAS, «El salvamento del tesoro artístico español durante la Guerra Civil y sus principales protagonistas», en las XIV Jornadas Internacionales de Historia del Arte "Arte en tiempos de guerra", GI de Historia del Arte, Imagen y Patrimonio Artístico, Instituto de Historia, Centro de Ciencias Humanas y Sociales, CSIC, Madrid, 11 al 14 de noviembre de 2008 (en prensa); http//www.mcu.es/ patrimonio/ docs/ MC/IPHE/ DonacionJoselinoVaamon-de.pdf (03/05/ 2009); J. Álvarez Lopera. La política de Bienes Culturales del Gobierno Republicano durante la Guerra Civil española, 2 Vols., Madrid, Ministerio de Cultura, DGBBAA, 1982; J. RENAU, Arte en peligro, 1936-1939, Valencia, Fernando Torres, 1980; M. T. LEÓN, La historia tiene la palabra (Noticia sobre el salvamento del tesoro artístico), Madrid, Hispamerca, 1977; J. A. GAYA NUÑO, Historia del Museo del Prado (1819-1976), Madrid, Everest, 1977; J. L VAamonde VAlencia. Salvamento y Protección del Tesoro Artístico Español durante la guerra 1936-1939. Caracas, imprenta Cromotip, 1973.
Figueras hacia Francia, con el objetivo de su venta a cambio de armas por el gobierno de la República, plan que pretendía interceptar el gobierno de Burgos. Dicho cuadro nunca fue custodiado en el castillo de Figueras, sino que las obras más importantes estuvieron en el castillo de Perelada. Esto es, las obras del Museo del Prado, El Escorial, el Palacio Real, el Palacio de Liria y la Real Academia de Bellas Artes de San Fernando. En Figueras se cobijaron otras obras de importancia: esculturas, tapices, documentos históricos y artes decorativas diversas $^{12}$. La novela no sólo consigue interesar al lector, sino que creo que ejerce una labor importante de concienciación en relación con la valoración de la institución en sí misma y de los bienes custodiados en ella, que en este texto aparecen despojados de su sede.

Ciertamente, quien dice la entidad, dice sus obras, pues "dos siglos después de abiertos los primeros museos nacionales, su historia nos cuenta que en su relación con las obras de arte actúan no sólo como custodios sino también como auténticos creadores de gran parte de su fama y su prestigio. Esta fama se sustenta del testimonio de las sucesivas generaciones que los visitan, y de su frecuente conversión en objeto tanto de estudio científico como de divagaciones literarias" ${ }^{13}$.

Un fragmento de La novela de un pintor $^{14}$ (1993), de Víctor Alperi, ensayista y periodista asturiano que también ha dedi-

-

12 Vid. A. COLORAdo CASTEllary, «El Tesoro Artístico y el fin de la guerra. De Cataluña a Ginebra», Algerich, I. y ARA, J. (eds.), Arte protegido. Memoria de la Junta del Tesoro Artístico durante la Guerra Civil, Madrid, Ministerio de Educación Cultura y Deporte, Secretaría General Técnica, Subdirección General de Información y Publicaciones, 2003, p. 63.

13 J. PORTús, Museo del Prado. Memoria..., Op. Cit., p. 88 .

${ }^{14}$ V. ALPERI, La novela de un pintor, Madrid, Ediciones Libertarias, 1993. 
cado páginas a la crítica de arte y que, posiblemente, aquí se inspira en la personalidad de Picasso, es significativo de ambas ideas: la fama y la importancia de los fondos del Museo, y la trascendencia posterior de estudios e investigaciones. En esta novela, El Museo del Prado es visita obligada y querida para el artista Pizolo, que vuelve a Madrid desde una larga estancia en Arles tras haber pasado por Barcelona. Vuelve invitado para dar una conferencia sobre su pintura y a pesar de no sentirse con fuerzas,

"Aceptó de todas formas, con el deseo de volver a visitar el Museo del Prado, la gran Pinacoteca que no veía desde niño, cuando un verano fue con su padre a Madrid para estudiar a los grandes maestros. Su admirado Velázquez, tantas veces estudiado y glosado, estaba frente a sus ojos de nuevo, lo mismo que Goya, el Greco, Murillo, el Bosco con su terrible Jardín de las Delicias (...) Todos los grandes estaban allí, admirables, dentro de sus ojos; ni en París, ni en Moscú ni en Roma, ni en los pequeños museos de provincias donde alguna vez aparece alguna obra maestra perdida en el tiempo, en los catálogos; perdida en toda obra de arte... Alli estaban todos los que tenían que ser" ${ }^{\prime \prime}$.

Pero es que, además, el personaje lleva en sus manos, como guía, una obra de referencia indudable para cualquier amante y estudioso de la institución: Tres horas en el Museo del Prado, de Eugenio D'Ors ${ }^{16}$, "que señalaba, guiaba y pontificaba con certeza y maestría"17, de la que extrae incluso algunos párrafos que le obligaron a pensar ${ }^{18}$.

${ }^{15}$ V. ALPERI, La novela de un pintor, Madrid, Ediciones Libertarias, 1993, p. 83.

${ }^{16}$ Vid. J. PORTÚS, «La actividad bibliográfica», Enciclopedia del Museo del Prado (dir. F. CALVO SERRALLER y M. ZugAZA MIRANDA), tomo I: temático, Alcobendas (Madrid), Fundación Amigos del Museo del Prado, TF, 2006, p. 163-165; Museo del Prado, Memoria..., Op. Cit., p. 102.

${ }^{17}$ Vid V. ALPERI, La novela de un pintor, Op.Cit. p. 83.

${ }^{18}$ Ibidem, pp. 85-86.
Cuando la literatura y el arte confluyen como intereses en la mente de un autor de novela, éste nos proporciona una lectura de imágenes muy personal en la que inciden, sin duda, su formación, el contexto de creación, los intereses de la sociedad y una cultura aprendida y compartida a lo largo de muchos siglos. Así, el cuadro/la pintura desde el siglo XV funciona como ventana que nos da acceso a una realidad, la que el pintor nos proporciona para que soñemos, nos instruyamos o nos deleitemos en su contemplación. De tal manera que durante cinco siglos el arte es preferentemente narrativo, el cuadro cuenta una historia del mismo modo que lo hace la novela, con la peculiaridad, como señala Manguel, de que "formalmente los relatos existen en el tiempo y las imágenes en el espacio (...) A diferencia de las imágenes, las palabras escritas fluyen constantemente más allá del encuadramiento de la página (...) Las imágenes, en cambio, se nos presentan a la conciencia de manera instantánea, contenidas por su encuadramiento dentro de una superficie específica -la pared de una caverna o de un museo- dentro de una superficie específica (...). Pero lo que vemos cuando recorremos las salas de una galería, cuando seguimos las imágenes en la pantalla u hojeamos un tomo de reproducciones, rebasa todos estos límites (...). En definitiva, lo que vemos no es un cuadro en un estado inmutable, ni una obra de arte atrapada en las coordenadas que el museo le ha asignado para guiarnos. Lo que vemos es el cuadro traducido a nuestra propia experiencia" ${ }^{19}$.

Y esto es lo que suele ocurrir en algunos casos con autores a los que la visión o el contacto con una obra de arte les lleva a trasladar una vivencia personal de una forma explícita, en algunas ocasiones, o implícita, pero muy clara, en otras. Igual

${ }^{19}$ A. MANGUEL, Leyendo imágenes. Una historia privada del arte, Bogotá, Editorial Norma, 2002, pp. 23-25. 
que el visitante del museo cuando se enfrenta a un cuadro tiene distintas posibilidades de acercarse a él, e inevitablemente tiende a construir un relato o a preguntarse en este sentido, el escritor que apuesta por la pintura como fuente de inspiración no lo hace asépticamente, sino que pone en relación su propia historia, imágenes guardadas en su retina, narraciones de tiempo inmemorial o del acervo más cercano, así como su formación y conocimientos al servicio de esa confluencia entre la realidad y la ficción que es la novela.

Por ejemplo, así ocurre con Faulques, el personaje principal de El pintor de batallas $(2006)^{20}$, obra de Arturo Pérez Reverte. Se trata de un fotógrafo, reportero de guerra con claros trazos autobiográficos, cuya mirada estaba de algún modo sesgada por su propia profesión, pues "pasó años acumulando documentación, visitando museos, estudiando la ejecución de un género que ni siquiera le había interesado en la época de estudios y aficiones juveniles" ${ }^{\prime 21}$.

Retirado en la torre de un faro, dedica sus máximos esfuerzos a pintar un mural, una pintura de batallas. Las fuentes de inspiración están en los museos y en los libros, pero sobre todo en las piezas de grandes museos. $\mathrm{Y}$ en concreto en el Prado, como La carga de los mamelucos y Los Desastres de la guerra, de Goya; en La victoria de Fleurus de Carducho; El incendio de Troya de Collantes, todas ellas en nuestra gran pinacoteca. Y en otras obras eminentes para la historia del arte, como las batallas de Paolo Ucello, de los Uffizzi; la obra de los muralistas mejicanos, o la batalla de San Quintín, de Luca Giordano, en El Escorial ${ }^{22}$.

${ }^{20}$ A. PÉRez ReVERTE, El pintor de batallas, Madrid, Alfaguara, 2006.

${ }^{21}$ Ibidem, p. 16.

${ }^{22}$ Vid. Ibidem, pp. 16-17.
Las reflexiones sobre la pintura y los grabados de Goya aparecen como un referente necesario en más de un momento:

"Qué curioso (...) que casi todos los pintores interesantes de batallas sean anteriores al siglo XVII. A partir de ahí nadie, excepto Goya, se atrevió a contemplar a un ser humano tocado de veras por la muerte, con sangre auténtica en vez de jarabe heroico en las venas (...) Luego tomó el relevo la fotografía. Tus fotos, Faulques, y las de otros. Pero hasta eso perdió su honradez, ¿verdad? Mostrar el horror en primer plano ya es socialmente incorrecto"

Goya, su obra y el Museo del Prado vuelven a aparecer hasta cuatro veces en el relato. Recuerda el Duelo a garrotazos de Goya, el más crudo símbolo de guerra civil que se había pintado nunca: "Comparado con aquello el Guernica picassiano era un ejercicio de estilo (...) El viejo don Francisco era tan moderno que hace daño" ${ }^{23}$. Pero no es la última vez. En el recorrido del pintor de batallas por diecinueve museos de Europa y América, fotografiando cuadros y gentes que los contemplaban, nos ofrece una visión fotográfica de las salas de un museo, el Prado:

"Los visitantes aislados o en grupo, los estudiantes y los guías artísticos en los momentos en que la sala estaba vacía, o cuando era tan numeroso en público que el cuadro apenas podía verse. Trabajó así durante cuatro años, seleccionando, descartando, hasta que reunió una serie última de veintitrés fotografías, que incluía desde los ojos enloquecidos del hombre que apuñalaba a un mameluco en El dos de mayo de 1808 en $\mathrm{Ma}$ drid, apenas entrevistos entre las cabezas de la gente que abarrotaba la sala goyesca del Museo del Prado" ${ }^{24}$.

Pérez Reverte indaga sobre el arte de la representación. En la ficción, el fotógrafo que fue, trasunto del propio autor, opta por volver a la creación artística en la figura de

\footnotetext{
${ }^{23}$ Ibid., p. 98.

${ }^{24}$ Ibid., p. 231.
} 
Faulques, empeñado en abordar la creación de un gran mural que sea exponente del caos aparente que es la guerra como espejo de la vida. Y para ello, el autor que indaga a lo largo de toda la novela sobre la maldad humana, lucha denodadamente como pintor de batallas en encontrar la supuesta estructura compositiva, la trama geométrica de la pintura como representación de una idea, que él como fotógrafo ya había logrado.

La obra de otro pintor importante en las colecciones del Museo del Prado, Sánchez Coello, es escogida por Ángeles Saura, hermana del pintor Antonio Saura, que publica en el año 2001 La duda. El protagonista de esta novela es un catedrático de Historia del Arte, César Rinconeda, que teme el descrédito de sus investigaciones sobre Francisco Meltan ante los hallazgos de una historiadora joven. El texto se inspira en una visita al Museo del Prado con su hermano Antonio Saura, el pintor informalista. Lo descubrimos al final de la novela que incluye el apartado "Sobre $L a d u d a$ ": "una especie de pequeño relato íntimo dentro del texto" ${ }^{\prime 25}$, dice la autora. Aquí cuenta como cinco años antes, en uno de los viajes de Antonio Saura a Madrid, cumplieron con lo que era un rito para el pintor: hacer una visita al Museo del Prado y visitar a Velázquez, Goya, Rembrandt y el retrato de Felipe II atribuido durante mucho tiempo a Sánchez Coello ${ }^{26}$, y en aquel momento adscrito ya a la producción de la pintora italiana Sofonisba Angisciola o Anguissola ${ }^{27}$.

\section{-}

25 Á. SAURA, La duda, Barcelona, Galaxia Gutenberg, 2001, 111; Vid. también R. SALAS, «El diálogo con su hermano pintor inspira a Ángeles Saura su primera novela», El País, Madrid, 19/04/2001.

${ }^{26}$ En 1990 (junio-julio) se había presentado en el Museo del Prado la Exposición "Alonso Sánchez Coello y el retrato en la corte de Felpe II".

${ }^{27}$ Vid. J. SÁEz DE MIERA, Jesús, «Felipe II, Sofonisba Anguissola, Felipe II, un monarca y su época. Un príncipe del Renacimiento, Sociedad Estatal para la Conmemoración de los Centenarios de Felipe II y
Saura se quedó unos momentos solo ante el cuadro, como muchas veces hacía, y cuando se volvió a unir al grupo les dijo: "Es increíble, un cuadro que parecía tan masculino y tan español, resulta que es de una pintora, y además, italiana, ¿no es fantástico?"28

Este fue el detonante de la novela de Ángeles Saura que, sobre la marcha, tomó unas notas: "sería la historia de un hombre mayor actual, español, cultivado, pintor o profesor, de aspecto parecido al de Durero, que siempre me atrajo, de temperamento exagerado, exclamatorio, y que, tras haber dedicado toda su vida al estudio de un pintor español, y en especial al de una de sus obras considerada por él más perfecta, de golpe, se encuentra con que esa obra no solo puede ser de otro pintor, sino, que además ese pintor puede ser una pintora, $\mathrm{y}$ además , extranjera" ${ }^{29}$.

De hecho, el libro comienza con la siguiente exclamación: "¡Nunca, mujer absurda, tú nunca pudiste pintarlo! ${ }^{30}$, tan distinta a la apreciación admirada del pintor Antonio Saura ${ }^{31}$. La autora sitúa el momento en que surgió la idea en la vuelta a casa desde el Museo del Prado. Pensó que allí había un buen arranque para un relato, lo uniría a otro que intentaba escribir y quedó plasmado en unas notas. Entonces corría el año 1996 y Antonio Saura enfermó en 1998. Durante un año, se veían con frecuencia entre semana y mantenían largas conversaciones sobre temas diversos: pintura, arqueología, música, arquitectura, literatura, familia, historia, museos... Todo resultaba igual de apetecible en una rela-

Carlos V y Museo del Prado, 1998, pp. 400-401, y C. GARRIDO, «Estudio técnico», Alonso Sánchez Coello y el retrato en la Corte de Felipe II, pp. 226-228.

${ }^{28}$ Á. SAURA, La duda, Op.cit., pp. 112.

${ }^{29}$ Ibidem, 112-113.

${ }^{30}$ Ibidem, p. 11.

${ }^{31}$ Vid. supra, nota 28. 
ción abierta y maravillosa. En esas charlas apareció su novela y Saura opinaba y aportaba ideas sobre el modo de ser del personaje, incluso se ofreció a ilustrar el libro. De aquellas ideas surgió un esbozo de obra en varias hojas a finales de 1998 y un personaje cuya obsesión por mantener la autoría de uno de sus cuadros favoritos, puesta en cuestión por la investigadora, urde una trama de envenenamiento contra ella. En la narración se entretejen descripciones de la obra en cuestión, de otras obras del museo, o de situaciones como la inauguración de la Sala Meltan en la pinacoteca.

Ahora bien, lo curioso, en este caso, es la explicación de algo a lo que no nos tienen acostumbrados los autores: la existencia de ese paralelismo entre lo real y lo ficticio, de un proceso de creación entre la novelista y el pintor fallecido en junio de 1998, al cual dirige las últimas palabras de ese relato íntimo: "Y ahora, Antonio, aquí está, quiero presentártela. Porque ya tiene nombre y timbre y cuadro fetiche, y tiene, para darle cuerpo, historia, recuerdos, pasiones nuevas, principio y fin (....) No sé si alcanza inflexiones y pasiones masculinas, ni si yo las he sabido expresar bien. Ojalá. Pero sí sé que ha crecido intentando no apartarse de la intensidad ni del humor, y como me ha recordado muchas veces lo que hablamos en el hospital sobre la capacidad que una mancha o una palabra tienen para potenciar o destruir un ritmo, y además me ha enseñado la sensualidad de tiznarme con esas manchas-palabras desparruchando sonoridades y matices como si se tratara de tubos de pintura, me parece que puede gustarte, y que, juntos podemos ir alguna vez a hacerle una visita. Porque tiene poco de nosotros, ya lo verás, en realidad muy poco, pero en su aliento verás también que, de alguna forma, estamos los dos ${ }^{\prime 32}$.

\footnotetext{
${ }^{32}$ Ibidem, p. 118.
}

Existen otro tipo de obras protagonizadas por personajes inmortalizados en la pintura, que cobran vida en la ficción literaria, en un recurso posiblemente iniciado por el último escrito de Manuel Mújica Laínez, Un novelista en el Museo del Prado $(1984)^{33}$, en el que "cada personaje esculpido o pintado es como el fantasma o la proyección de sí mismo y al desgajarse del sitio glorioso que ocupa y en el Catálogo lo encierra, deja en su lugar una imagen (la imagen de una imagen), un quieto reemplazante exacto que engañará pasajeramente los alcances de la humana vigilancia." ${ }^{34}$

Quizás en este sentido, una de las obras más significativas sea La infanta bai$l a^{35}$, de Manuel Hidalgo (1997), una novela que permite ver el funcionamiento del $\mathrm{Mu}$ seo del Prado en una situación sorprendente y más que inesperada y límite. La novela sitúa la acción de un modo cinematográfico, no en vano su autor es crítico de cine y guionista, con el aviso apremiante de un vigilante de sala a su compañero para que avise a la consola, es decir, el lugar donde se centralizan todos los sistemas de seguridad, pues

"Lo que ha ocurrido en las salas XI,XII,XIV,XV y XXVII no ha sucedido en las demás. Ni en Ribera, ni en Murillo, ni en Zurbarán, que ocupan salas contiguas, se observa el mismo fenómeno. Sólo Velázquez parece estar afectado (...). Lo ha descubierto, viniendo por la gran galería de la planta principal, en Las Lanzas. Ni rastro de Spinola ni de Nassau, ni de sus

${ }^{33}$ Vid. M. VILLALBA SALVADOR, «Un panorama acerca de la novela y los escritos de arte en la narrativa de finales del siglo XX y comienzos del siglo XXI», en Ficción y realidad en la novela contemporánea española. Actas de las Jornadas de Narrativa Contemporánea Española, M. D. DE Asís GarRote y A. CALVO ReVILla (eds.), Madrid, Universidad San Pablo CEU, 2005, pp.144145.

${ }^{34}$ M. MÚJICA LÁINEZ, Un novelista en el Museo del Prado, Barcelona Seix Barral, 1987, p. 10.

${ }^{35}$ M. HIDALGO, La infanta baila, Barcelona, Plaza \& Janés, 1997. 
generales y capitanes, ni de los tercios ni de las tropas holandesas. Sobre la tela solo los campos calcinados de Breda, las lejanas siluetas de pueblos y casas, las tiendas de los campamentos, las humaredas. El cuadro, impecable, en su sitio, sin indicio de haber sido tocado o manipulado (...). Después, atónitos y con las pulsaciones disparadas, han visto lo demás: la fragua del Vulcano sin Apolo ni los Herreros, sólo el fuego en el horno; la parra, el tonel, la jarra, pero ni Baco, ni los ocho Borrachos; las encinas de El Prado, las cumbres nevadas y azules de Guadarrama, pero ni Felipe $I V$, ni don Fernando de Austria, ni el Príncipe Baltasar Carlos, ni sus mastines, ni sus podencos; el taller de hilar con su cortina roja y su tapiz al fondo, pero no las hilanderas, ni siquiera el gato; los vestigios de la batalla de Fuenterrabía, pero no el Conde Duque de Olivares; ni los bufones, ni Esopo, ni Menipo; ni las reinas Isabel y Mariana, ni la Virgen con Jesucristo y Dios Padre. Sólo las nubes, también la paloma del espíritu Santo había volado. Oh, y tampoco están la infanta Margarita, ni sus Meninas. Ni Velázquez pintando" ${ }^{\prime 36}$.

A partir de ahí no es difícil encontrar a la Infanta Margarita y sus meninas en el metro, a Calabacillas en el parque infantil frente al Museo Thyssen; a don Fernando de Austria y su podenco a la altura del Colegio del Pilar, en Príncipe de Vergara, y así un largo etcétera. Todo ello mezclado con distintas historias de personajes que pululan por las calles de Madrid y por la reacción en el interior del Museo del Prado.

El autor nos descubre la cotidianeidad de la Pinacoteca, las reacciones en momentos problemáticos. La llegada del Director, los conservadores, restauradores y miembros del Área de Documentación, las dos secretarias del director, la llegada de un historiador del arte y profesor universitario que, enterado por la radio de lo que está ocurriendo, piensa en la posibilidad de que se esté cumpliendo un posible maleficio sobre las pinturas en un día tan especial como el del IV Centenario de Velázquez. Algo que leyó en un libro hace tiempo en

\footnotetext{
${ }^{36}$ Ibidem, pp.15-17.
}

un relato de viajeros franceses en el siglo XIX.

Pero es curioso ver la interrelación entre la literatura y el arte no sólo en cuanto que este se convierte en tema de novela, sino que en el despacho del Director las personas allí reunidas no dan crédito e interpretan lo que está ocurriendo como algo tan irreal que "es cosa de novela". Así se lo hace saber un conservador al profesor de Universidad:

"Lo siento, señor Ugarte, pero todo esto es absurdo. ir a una cartuja a buscar no sé que manuscrito!. Es cosa de novela. Una institución como el Prado no puede mezclarse con un planteamiento semejante, seríamos el hazmerreír de los museos del mundo" ${ }^{\prime 37}$.

Aparece aquí intuida la idea de la novela dentro de la novela, recurso conocido en la historia de la literatura española. Pero, más importante y en relación con los procedimientos artísticos, es ver la sucesión de imágenes que podemos relacionar con la práctica, tan utilizada en la pintura de los Siglos de Oro, del cuadro dentro del cuadro $^{38}$, de la que es maestro Velázquez. El pintor se ve, súbitamente, fuera del cuadro, en la Basílica, la sala conocida en la pinacoteca con este nombre, en donde se encuentran Las Meninas ${ }^{39}$. El novelista denota haberse documentado y concede a Velázquez algo que el mismo pintor reivindica desde su gran obra: la dignidad de la pintura como arte liberal, de tal modo que "percibe que, en esta aventura, imprevista e imprevisible, le ha sido concedida, como creador de las imágenes, la conservación de un leve aliento de inteligencia, de discernimiento y de voluntad. A sus criaturas sólo

\footnotetext{
37 Ibidem, p. 73.

${ }^{38}$ Vid. J. GÁllego, El cuadro dentro del cuadro, Madrid, Cátedra, 1978.

${ }^{39}$ Vid. Ibidem, pp. 66-70.
} 
les serán dadas las garantías de algunas sencillas emociones" ${ }^{\prime 40}$.

El autor aprovecha esta circunstancia para hacer una visita por algunas de las salas más importantes, en este caso de la mano de Velázquez, que es capaz de analizar muchas cosas:

"El más allá es la pintura, es la tela que mantiene impresionado lo visto y lo vivido, el otro lado del tiempo del que nadie viene a este lado, como nadie viene al presente desde el pasado" ${ }^{\prime 1}$.

Durante el paseo por las salas del recinto rememora lo que pintaba, descubre la falta del resto de los personajes, se da cuenta que está en un lugar que es sede de colecciones de pintura y busca los cuadros que el compró por encargo de Felipe IV. En su recorrido se detiene en el retrato ecuestre de Carlos V en la Batalla de Mülhberg, de Tiziano; en el Lavatorio de Tintoretto, que "le conmueve por su magnificencia y por su técnica"; busca a Rubens, lo recuerda; y se encuentra con Goya y las pinturas negras y, entonces, experimenta la libertad absoluta y tiembla ante la sorpresa.

Aquí los personajes dan un salto en la noche, del cuadro y de la sala donde se encuentran ubicados, a la gran sala de las Meninas, y de ahí al exterior del Museo. Se ha producido, por lo tanto, un salto más en el recurso iniciado por Manuel Mújica Laínez, y que descubrimos un año más tarde en uno de los personajes principales de $E l$ enigma del pintor ${ }^{42}$ (1998), de José María Baldasano, corredor de comercio que inicia su actividad literaria con esta novela. En ella uno de los personajes de Los Borrachos, de Velázquez, salta del cuadro al Museo y, en sentido inverso a los relatos anteriores, introduce a un vigilante del Museo a través

\footnotetext{
Ibidem, pp. 66-67.

${ }^{41}$ Ibidem, p. 67.

42 J.M. BALDASANO, El enigma del pintor, Madrid, Ediciones Literarias, 1998.
}

del lienzo en el Madrid del siglo XVII y el entorno de Velázquez.

Por otra parte, al comienzo del artículo señalaba cómo el Museo del Prado trasciende lo artístico y se proyecta en lo literario. El recurso utilizado por Mújica Laínez, fuente para los textos de Manuel Hidalgo o José María Baldasano, e incluso las novelas de estos autores, lo encontramos durante el año 2005 en una actividad organizada por el Área de Educación que supuso un programa gratuito de representaciones denominado "Teatro en el Prado". Al modo de los personajes de Mújica Laínez, el rey Felipe IV acompañado por su mujer, Mariana de Austria, se convertía en protagonista de "El rey se divierte" y paseaba por la pinacoteca junto a Calderón de la Barca, María Inés Calderón "La Calderona" y otros personajes de la época que le distraen a medida que ve los cuadros de su colección. Del mismo modo, se organizó una dramatización de El Sitio de Breda (1626), de Pedro Calderón de la Barca, relacionada con el cuadro de Velázquez, La rendición de Breda o Las lanzas ${ }^{43}$. Los textos literarios del Barroco y sus personajes amenizando las salas y galerías del Museo del Prado.

Asimismo, vigilantes, conservadores, restauradores o directores de museos, son profesiones que han inspirado a los autores de la narrativa contemporánea española, bien como protagonistas o como personajes secundarios. Es lo que ocurre en Corazón tan blanco (1992), de Javier Marías. El Museo del Prado aparece aquí de una manera más bien fugaz, en la figura de Ranz, padre del protagonista de la novela, que fue "experto de plantilla del Museo del Prado", es decir, conservador de la institución. Y como señala el autor,

43 Vid. http//www.museodelprado.es/mas-parado/ lainstitucion/memorias-anuales/ Memoria_2005 . pdf, p. 105-106 (14/04/2009) 
"nunca director ni subdirector, nunca alguien visible, aparentemente un funcionario que pasaba todas las mañanas en una oficina (...).Mi padre se pasaba los días encerrado efectivamente en un despacho al lado de las obras maestras y no tan maestras que tanto le apasionaban. Mañanas enteras en la vecindad de cuadros extraordinarios, a ciegas, sin poder asomarse a verlas, a ver como las miraban los visitantes. Examinaba, catalogaba, describía, descatalogaba, investigaba, dictaminaba, inventariaba, telefoneaba, vendía y compraba"$^{\prime 4}$.

Era reclamado constantemente por otros museos e instituciones para peritar y expertizar en materia de arte. Descubrimos a través de su descripción problemas de la vida cotidiana de un museo. Desde esa sensación tan generalizada entre sus trabajadores de no poder conocer a fondo la colección por falta de tiempo material, hasta la constante preocupación por la conservación del patrimonio custodiado:

"Cuando trabajaba en el Prado recuerdo su pánico a cualquier accidente o pérdida, a cualquier deterioro y al más mínimo desperfecto, así como a los guardianes y vigilantes del museo, a los que, según decía, habría que pagar maravillosamente y procurar tener muy contentos, ya que de ellos dependía no sólo la seguridad y el cuidado, sino la propia existencia de las pinturas. Las Meninas, decía, existen gracias a la benevolencia o perdón cotidiano de los guardianes, que podrían destruirlas en cualquier momento si lo quisieran, por eso hay que mantenerlos orgullosos y alegres y en estado psíquico satisfactorio. El, con diversos pretextos (no era su tarea, no lo era de nadie), se encargaba de saber como les iba la vida a esos vigilantes, si estaban tranquilos o por el contrario alterados, si los agobiaban las deudas o, por el contrario, se defendían, si sus mujeres o sus maridos (el personal es mixto) los trataban bien o los brutalizaban (...) siempre interesándose y velando por ellos para salvaguardar las obras de los maes-

44 J. MARÍAS, Corazón tan blanco, Barcelona, Anagrama, 1992, p. 114. tros, protegerlas de sus posibles iras o arrebatos de resentimiento" 45

También Fernando Royuela en El Prado de los monstruos (1996), presenta a un vigilante que presta sus servicios en el $\mathrm{Mu}$ seo del Prado, que se propone tramar un plan terrible en un deseo irrefrenable de captar la atención nada menos que con la quema de una obra tan emblemática para el Prado como el Cristo de Velázquez. O la figura del restaurador, protagonista de Tela de Juicio $(2000)^{46}$, de Pedro Jesús Fernández, experto en Historia del Arte y conocedor de la institución, de la que fue subdirector adjunto, y autor de esta novela de intriga que se inicia con la misteriosa desaparición de un restaurador del Museo del Prado, Alberto Fernández Garibay, cuya trama se basa en su búsqueda. Éste defiende la autoría de un retrato de don Luis Méndez de Haro, valido de Felipe IV, por Juan Bautista del Mazo, yerno de Velázquez, lo que supone un enfrentamiento con la dirección del Museo que aboga por la autoría velazqueña.

Asimismo, la narrativa breve nos muestra ejemplos de relatos inspirados en obras de arte pertenecientes a los fondos del Museo del Prado. Un figura emblemática de la literatura española, como es José Jiménez Lozano, establece un paralelo entre los artistas y los escritores como interiorizadores de la cultura, ya que "el artista como el escritor- no es sólo un individuo ni primordialmente un individuo, sino un "yo" que carga con su mundo de carne y sangre, y con el de los demás; con su entorno y su cultura, pero también con otras culturas por la lectura y la conversación, la experiencia y la memoria; y, luego, con el

45 Ibidem, 118.

${ }^{46}$ P. J. Fernández, Tela de juicio, Madrid, Grupo Santillana de Ediciones, 2001. 
mundo de los sueños, las esperanzas y los terrores, y los trances visionarios" ${ }^{\prime 47}$.

No se podría decir mejor. De todas estas realidades se encuentran ejemplos en los relatos breves sobre arte pues, bien debido a intereses estrictamente de creación, bien a planteamientos de divulgación o de mera reflexión, el hecho es que nuestros autores optan por los temas de arte retomando una tradición existente en las letras españolas en el mundo contemporáneo desde comienzos del siglo $X X^{48}$. $\mathrm{Y}$ así encontramos escritores que crean relatos de ficción a partir de personajes ideados previamente por un pintor o escultor, caso de Eliacer Cansino o Miguel Fernández Pacheco; narraciones cuyo punto de partida son obras de arte $u$ objetos que han quedado grabados en su memoria, como el propio Jiménez Lozano, que no podemos de dejar de mencionar aquí.

Vuelvo a citar a Jiménez Lozano, cuya reflexión acerca del significado de los objetos es sumamente reveladora pues entiende que son portadores de sentido, lo que le hace en numerosas ocasiones detenerse en su contemplación $\mathrm{y}$, sobre todo, trasladarnos las confidencias de que es objeto:

"Estas piezas u objetos silenciosos -como las pinturas calladas que de ellos luego se han hecho- nos hacen muchas confidencias" ${ }^{\prime 49}$.

Éstas le sirven para rescatar su importancia. En muchos de sus cuentos, pero también en sus artículos de prensa, convi-

${ }^{47}$ J. JiMÉNEZ LOZANO y G. GALPARSORO, Una estancia holandesa. Conversación, Barcelona, Anthropos, 1998, p. 11.

${ }^{48}$ Vid. M. VILLALba SALVADOR, «Un panorama acerca de la novela y los escritos de arte en la narrativa de finales del siglo XX y comienzos del siglo XXI», en Ficción y realidad..., Op. cit., pp. 131-135.

${ }^{49}$ J. JIMÉNEZ LOZANO, «Una estancia con cosas en "El Prado"», Ni venta ni alquilaje, Madrid, Huerga y Fierro, 2002, p. 171. ven las obras de arte o las piezas arqueológicas, convertidas en auténticos objetos parlantes con situaciones de la vida cotidiana ${ }^{50}$. Por ejemplo en Las mujeres del cuadro, cuyo protagonista es una ordenanza del Museo del Prado que al final de la jornada pasa las horas contemplando el cuadro de Las Tres Gracias, de Rubens. Y continúa en esta actitud al llegar a casa, donde tiene una gran reproducción, de tal manera que crea gran confusión en su mujer,

"hasta aquel día en que ella le vio dándose señas en la calle con una mujer y entró en sospechas, y averiguó que era una estanquera; y fue allí al estanco, y entonces se dio cuenta de que la estanquera era el retrato mismo de aquellas mujeres desnudas y con tantas carnes como ellas. Y comprendió que su marido le había estado engañando mucho tiempo con la estanquera y con las mujeres del cuadro. Pero no dijo nada, porque siempre él la había estado diciendo que se alimentara, que se alimentara. Pero ni aún así, porque aunque se hubiera alimentado, las mujeres del cuadro y la estanquera eran muy rubias y muy blancas, y ella no. De manera que eso fue lo que le dijo a su vecina: Que las peores son las del cuadro, que a la estanquera ya le diré yo cuatro cosas. Y que se alimentara, que se alimentara" ${ }^{21}$.

Los relatos de Jiménez Lozano son ventanas abiertas a la vida cotidiana, a los recuerdos y los sentimientos. En palabras suyas, "la documentación de un narrador está dentro de sí mismo" ${ }^{\prime 2}$, y en estos cuentos brota de su memoria, de su ingente

${ }^{50}$ Vid. J. JIMÉNEZ LOZANO, «El poder de una llama», Ni venta ni alquilaje, Madrid, Huerga y Fierro, 2002, pp. 277-280; «El buey de Rembrandt», Ni venta ni alquilaje, Madrid, Huerga y Fierro, 2002, pp. 373-376; «El Museo», en Antología de cuentos (A. MEDINA Bocos Ed.), Madrid, Cátedra, p. 315.

51 J. JIMÉNEZ LOZANO, "Las mujeres del cuadro», en Antología de cuentos, A. MEdina Bocos (ed.), Madrid, Cátedra, p. 281.

${ }^{52}$ Expresión utilizada por José Jiménez Lozano en el transcurso de su intervención en la IV Jornadas de Narrativa "Realidad y ficción en la narrativa Contemporánea Española", CEU, Instituto de Humanidades Ángel Ayala, Madrid, 14 de febrero de 2007. 
bagaje cultural, en una suerte de naturalidad apabullante. Al tiempo que nos pone delante el cuadro de Rubens, su contexto y su esencia, nos revela el sentimiento humano cargado de cotidianeidad. En su narrativa es capaz de desvelar con un fogonazo un sentimiento, una pasión humana, extremadamente condensados. Apasionado por la historia de los hombres y de la belleza, nos deja en sus escritos numerosas reflexiones sobre el artista de hoy y el de otros tiempos, sobre la creación artística en cuentos, diarios, artículos y ensayos que revelan una sensibilidad muy especial ${ }^{53}$.

Uno de los cuentos publicado en Un dedo en los labios, lo dedica a Maria Bárbola, la enana de Las Meninas, de Velázquez, quizás uno de los personajes de la pintura más llamativos para la literatura ${ }^{54}$. En él descubrimos al personaje en toda su humanidad, mostrando su felicidad al verse en el cuadro:

"Pero, luego, cuando el pintor acabó la gustó mucho cómo había quedado el retrato $y$, como colgaron aquel cuadro en una galería de Palacio, a veces iba ella, la María Bárbola, allí, con los otros enanillos y sabandijas, y bufones, o idiotas, y les iba señalando: ésta es la infantita y éste es Nicolasillo, y el perro, y los señores, y el hombre que abría las puertas, y los reyes en el espejo,

${ }^{53}$ J. JIMÉNEZ LOZANO, Ni venta ni alquilaje, Madrid, Huerga y Fierro, 2002; Los cuadernos de letra pequeña, Valencia, Pre-Textos, 2003; J. M. PARREÑO, J. JIMÉNEZ LOZANO, A. PORTERA SÁNCHEZ, Aún aprendo: últimas obras de Tiziano a Tàpies, Segovia, El Museo, 2007.

${ }^{54}$ En el año 2004 M.T. ÁLVAREZ publicaba El secreto de Maribárbola (Madrid, Ediciones Martínez Roca, 2004), enana de origen alemán que aparece en el cuadro de las Meninas junto a Nicolás Pertusato. Su personaje es un recurso para introducir al lector en el ambiente madrileño del siglo XVII con motivo de la sucesión al trono de Carlos II. También es Maribárbola quien relata una de las Siete Historias para la infanta Margarita, de Miguel Ángel Pacheco (Madrid, Siruela, 2001), en concreto "La historia del siervo de Dios Juan Arconado". Y es uno de los personajes del cuento $\mathrm{La}$ infantita quiere buñuelos, de Asun Balzola (Madrid, SM, Barco de Vapor Museo, 2001). y el pintor, y al final de todo, señalaba su retrato allí en el cuadro y decía riéndose: -Y ésta soy yo, ¿no me veis?" 55 .

Hay además un sector importante hoy en día en al producción editorial, que es el de la literatura infantil y juvenil, que presenta títulos muy interesantes. Cuentos, relatos y novelas cortas, como es el caso de El misterio Velázquez, de Eliacer Cansino, catedrático de Filosofía en un Instituto de Enseñanza Media en Sevilla. Autor de un relato muy bien trabado y enormemente ágil basado en la figura de Nicolasillo o Nicolás de Pertusato, uno de los personajes de Las Meninas, obra que ha recibido el Premio Lazarillo 1997 y en la que me detendré más adelante. El mismo año la Editorial Siruela sacaba a la luz un conjunto de relatos inspirados en representaciones de figuras del santoral en Una mano de santos ${ }^{56}$, de Ana Rossetti, que escoge dos cuadros del Museo del Prado: Santa Barbara, de Robert Campin o Maestro de la Flemalle, y Santa Casilda, de Zurbarán. El primero lo toma como fuente de inspiración para hacer una reinterpretación, a manera de cuento, de la leyenda sobre Santa Bárbara contada por Jacobo de la Vorágine, la fuente más importante de la hagiografía cristiana. Una narración que actualiza valores de la santa para nuestra sociedad fundamentalmente laica y con un trasfondo de valoración de la figura femenina. Juega con enorme habilidad con el lenguaje y transmite los valores implícitos en el cuadro, bien a través de las imágenes de el lirio/la pureza, el agua/la fuente de la vida, el libro/la sabiduría, la torre/la fortaleza, o bien a partir de los colores: el rojo/el amor y el verde/la esperanza, logrando que sean sorprendentemente actuales, en una suerte de moraleja final en la

-

${ }^{55}$ J. JIMÉNEZ LOZANO, «María Bárbola», en Antologí de cuentos, A. Medina Bocos (ed.), Madrid, Cátedra, p. 306.

${ }^{56}$ A. RossetTI, Una mano de Santos, Madrid, Siruela, 1997. 
que se ponen en valor las cualidades de la santa y se traen a colación situaciones sufridas actualmente y actitudes que se pueden trasponer, porque como dice Ana Rossetti:

"Además esta historia no es una fábula. Es verdad. Todavía es verdad.

Aún hay chicas asesinadas por no llevar un velo, por querer estudiar, por pretender dirigir sus propios destinos. (...)

Pero esta no es una historia de chicas y sólo para chicas.

Todos tenemos una torre en nuestro interior. interior $^{\prime \prime 57}$

Parte de nosotros permanece en esa torre

El cuadro de Santa Casilda, de Zurbarán, da lugar al relato Más allá no hay monstruos, protagonizado por la princesa Poema, portadora en su delantal de "una rosa traspasada por innumerables rayos: la Rosa de los vientos, con todas las direcciones desde las que se pueden mirar las cosas, pues la realidad no tiene un única manera de mostrarse" ${ }^{\prime 58}$. Cuenta la leyenda que santa Casilda ayudaba a los prisioneros, les llevaba panes en el delantal y, sorprendida por su padre, aquellos se convirtieron en rosas. Se trata de un sugerente relato en el que la autora "propone una mirada distinta para comprender el misterio" ${ }^{\prime 59}$.

Cuatro años más tarde los personajes de Las Meninas protagonizan las Siete historias para la infanta Margarita ${ }^{60}$, de Miguel Fernández Pacheco (2001), contadas todas ellas en el taller de Velázquez, mientras éste pinta su gran obra para entretener a la infantita por deseo del rey Felipe IV.

\footnotetext{
${ }^{57}$ Ibidem, pp. 44-45.

${ }^{58}$ Ibidem, p. 83

${ }^{59}$ Ibid., p. 84.

${ }^{60}$ M. A. FERNÁNDEZ PACHECO, Siete historias para la Infanta Margarita, Madrid, Siruela, 2001.
}

La acción transcurre en unas horas de la mañana y en ella se hilan siete historias de amores, piratas, encantamientos, hadas, príncipes y princesas que cada uno de los personajes del cuadro relatan, en una estructura cerrada de siete cuentos dentro de un cuento. Entre ellos está la Verdadera historia del perro Salomón, también galardonado con el premio Nacional de Literatura Infantil y Juvenil 2000.

En cuanto a El misterio Velázquez $(1998)^{61}$, la novela de Eliacer Cansino, me gustaría dedicarle especial atención, por tratarse de una narración que nos introduce de lleno en el mundo de Nicolás de Pertusato, el bufón que aparece junto a María Bárbola en "La Familia" o Las Meninas. La novela, escrita en forma autobiográfica crea un suceso de ficción en torno a algo sobre lo que todavía los investigadores siguen deliberando: la interpretación de la gran pintura de Velázquez. Lo cual indica hasta qué punto las grandes obras, las obras clásicas, conceden constantes relecturas e interpretaciones. Ahora bien, me interesa resaltar que, a través de esta narración, protagonizada por uno de los bufones de la corte de Felipe IV, se ha conseguido trasladar al mundo de la ficción literaria algunas de las grandes preocupaciones y logros de Velázquez en su obra. En primer lugar, la figura del protagonista. Cuando Velázquez acomete la serie de los bufones para la Torre de la Parada, se siente con absoluta libertad a la hora de pintar. Los bufones eran locos, truhanes, hombres de placer, sabandijas de palacio, etc., que gozaban de la confianza y el favor del rey. En este caso, el pintor no tiene que halagar, como en el caso de reyes y príncipes. Por eso estos retratos expresan mejor que nada el concepto de la pintura de Velázquez: la belleza no está en lo representado, la belleza está en la pintura misma.

\footnotetext{
${ }^{61}$ E. CANSINO, El misterio Velázquez, Madrid, Bruño, 1998.
} 
Nicolasillo y su "padrino" en la novela, "El primo" quedan dignificados en la pintura velazqueña, y esto es lo que capta a la perfección Eliacer Cansino. Desde el principio de la novela, Nicolás de Pertusato recibe un mensaje: "Precisamente no queremos que crezcas. Nos gustas asi'" ${ }^{\prime 2}$. Uno de los primeros personajes que encuentra en su camino es Don Diego de Acedo, que gozaba de buena posición en la Corte y era un hombre culto, que le da una serie de consejos: “

"Voy a darte un consejo, muchacho: niégate desde el principio a hacer el payaso. Es la única manera de pararles los pies a todos esos mentecatos. Si cedes a sus presiones, después no lograrás hacerte respetar (...) Llámame Acedo. Todo el mundo me conoce así. Y aunque a mis espaldas me llaman El Primo, en la cara no son capaces de decírmelo. Esa es otra cosa que debes aprender. Procura que no te pongan un mote ridículo, y si lo hacen, que no sea con tu consentimiento",63.

Por la novela van desfilando algunos de los personajes del cuadro y del entorno de Velázquez: José Nieto, el aposentador de palacio, al que no apreciaba el protagonista; Juana Pacheco, esposa del pintor que llega a ser una madre para Nicolasillo; María Bárbola, siempre dispuesta a ayudarle, le hace saber que siempre podrá confiar en Velázquez. Y Juan de Pareja, discípulo de Velázquez al que realizó un magnífico retrato:

"Su rostro poseía una seriedad impecable, lo que contrastaba aun más con su exagerado sentido del humor. La nariz ancha y los labios gruesos, así como la fijeza de sus ojos y el cabello encrespado, le otorgaban el aire confuso de un noble metido a bucanero" ${ }^{\prime 64}$.

A mi modo de ver el gran tema de esta novela es la dignidad de las personas,

${ }^{62}$ E. CANSINO, El misterio... Op. Cit., p. 17.

${ }^{63}$ Ibidem, p. 22.

${ }^{64}$ Ibid., p. 77. unido indisolublemente al gran tema que movió a Velázquez y que queda de manifiesto en su autorretrato pintando su gran obra: la dignidad de la pintura como arte liberal. Velázquez se pinta a sí mismo pensando la pintura, no como mero artífice. $Y$ así lo ve Nicolasillo cerca del final de la obra:

"Inmediatamente cerré los postigos del ventanal para que desde el exterior la luz no anunciase nuestra presencia (...) la luz expandió un halo anaranjado e hizo aparecer ante nuestros ojos el cuadro y, en él, el rostro, cien veces sería poco decirlo, sereno, profundo, inteligente, pleno de nobleza de quien con seguridad esperaba nuestro gesto con ardiente impaciencia en el linde de la vida" ${ }^{\prime \prime 5}$.

También Nicolasillo, sabe comprender la importancia de los objetos: "Nunca he sentido como entonces la vida íntima de las cosas. Los lienzos inacabados parecían pedir a gritos la mano que concluyese su existencia definitiva. Los pinceles, la paleta, los tarros de pigmentos, el maniquí de madera, todo aquello que estaba sujeto a la voluntad de su dueño, y que por su decisión adquiría dinamismo, mostraba ahora la rotunda quietud de las cosas muertas".

Todos estos libros de un modo $\mathrm{u}$ otro nos familiarizan con el Museo del Prado y con los personajes que protagonizan los fondos de su magnífica colección, pero también con los artistas y con los cuadros en sí mismos, convirtiéndose en acicate para la visita al Museo. Tal como le ocurrió a Pizolo, el protagonista creado por Víctor Alperi que sintió que "el viaje a Madrid era fructífero; en pocos días, con las visitas al Museo, los paseos por las calles donde tomaba el pulso a la ciudad y sus gentes, su mente se enriquecía de sensaciones nuevas y casi desconocidas" ${ }^{\prime \prime 6}$.

${ }^{65}$ Ibidem, p. 130.

${ }^{66}$ V. ALPERI, La novela de un pintor, Op. Cit, p. 87. 
La labor realizada por los autores de estas obras, consciente o no, ejerce una labor importante en cuanto a la difusión y el conocimiento de nuestro patrimonio cultural, en concreto del que alberga el Museo Nacional del Prado, custodio de la memoria iconográfica de nuestro país, que se hace así accesible a los ciudadanos de una forma amena y distinta. Pues finalmente, como señala Alberto Manguel, "cada obra de arte se desarrolla atravesando incontables capas de lecturas, y cada lector o lectora tiene que retirar esas capas para llegar a la obra bajo sus propias condiciones. En esa lectura última (y primera) estamos solos. Es esencial poder (y querer) leer la obra de arte" ${ }^{\prime 67}$.

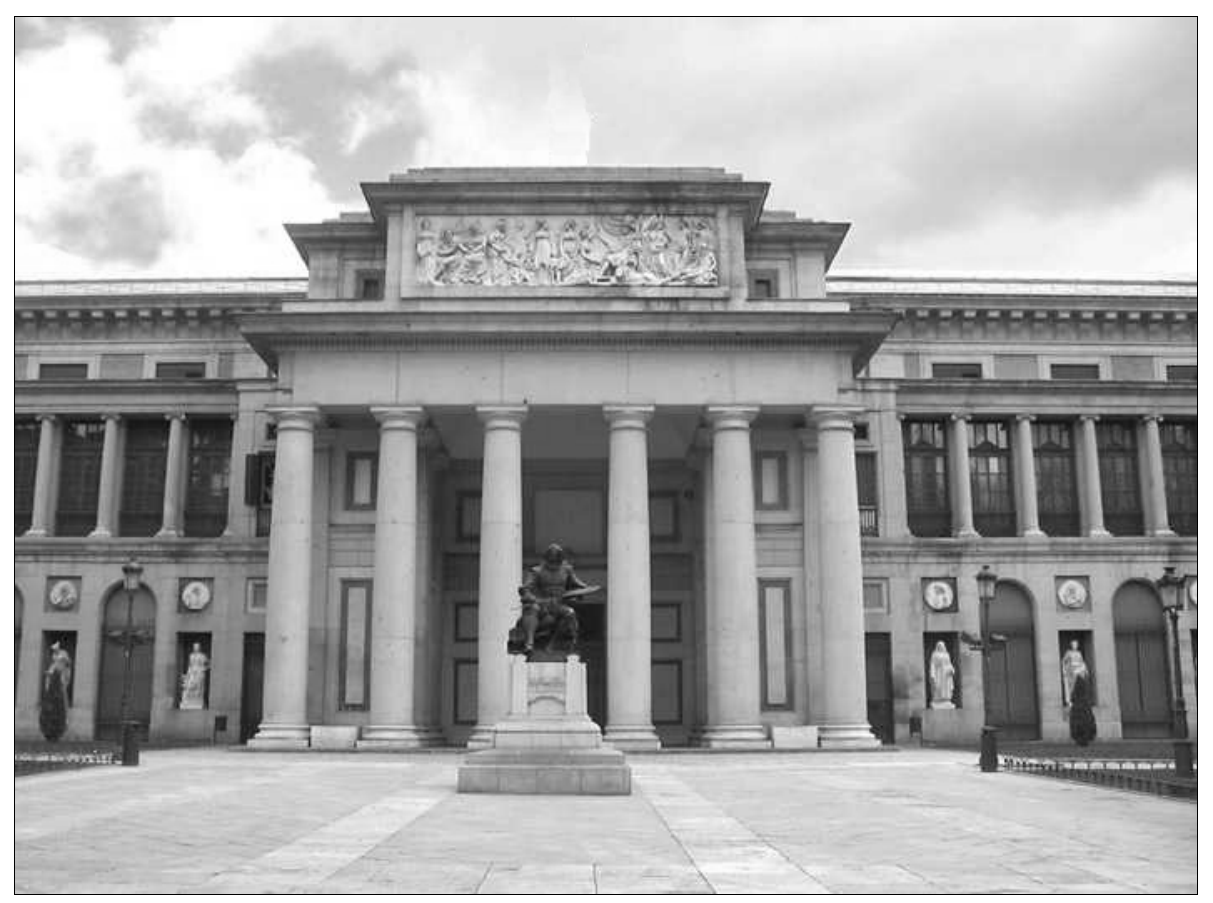

- Lám. 1. Fachada del Museo del Prado. 